\title{
Acacia hydaspica R. Parker ameliorates cisplatin induced oxidative stress, DNA damage and morphological alterations in rat pulmonary tissue
}

\author{
Tayyaba Afsar ${ }^{1}$, Suhail Razak ${ }^{2,3^{*}}$, Ali Almajwal ${ }^{3}$ and Muhammad Rashid Khan ${ }^{1}$
}

\begin{abstract}
Background: Cisplatin (CP) drug is platinum compounds used for the treatment of various human malignancies. However, adverse outcomes related to CP restrict its usage. Acacia hydaspica is a natural shrub with various pharmacological properties. The current investigation aimed to assess the protective potential of $A$. hydaspica polyphenol rich ethyl acetate extract (AHE) against cisplatin (CP) induced pulmonary toxicity.

Methods: Rats were divided into six groups. Group 1 served as control (saline); Group 2 (drug control) recieved single dose of CP (7.5 mg/kg i.p.) on 1st day; Group 3 (extract control) $(400 \mathrm{mg} / \mathrm{kg}$ bw, p.o.) received AHE for one week; Group 4 (Post-treated) and Group 5 (pretreated) received AHE (400 mg/kg bw/day, p.o) for 7 days after and before CP (7.5 mg/kg b.w., i.p.) respectively; Group 6 (Standard control) received silymarin ( $100 \mathrm{mg} / \mathrm{kg}$ b.w/7 days) before CP. At the end of dosing rats were sacrificed and pulmonary tissue samples were processed for the evaluation of antioxidant enzymes, oxidative stress markers, genotoxicity and histopathological alterations.
\end{abstract}

Results: CP caused body weights loss and increase pulmonary tissue weight. The CP significantly increases oxidative stress markers and decreases tissue antioxidant enzyme levels. Furthermore, CP induced deleterious changes in the microanatomy of pulmonary tissue by rupturing the alveolar septa, thickening of alveolar walls, and injuring the cells with subsequent collapse of blood vessels. AHE pretreatment returned MDA, NO, $\mathrm{H}_{2} \mathrm{O}_{2}$ production and improved tissue antioxidant enzyme levels to near normalcy. The histological observations evidenced that AHE effectively rescues the lungs from CP-mediated oxidative damage. CP induction in rats also caused DNA fragmentation which was restored by AHE treatment. Our results suggest that pretreatment more significantly improve CP induced deleterious effects compared with post treatment indicating protective effect. Potency of AHE pretreatment is similar to silymarin.

Conclusion: These findings demonstrated that A. hydaspica AHE extract might serve as potential adjuvant that prevents CP persuaded pulmonary toxicity due to its intrinsic antioxidant potential and polyphenolic constituents.

Keywords: DNA fragmentation, Pulmonary toxicity, Oxidative stress markers, Histopathological alterations

\footnotetext{
* Correspondence: ruhail12345@yahoo.com

${ }^{2}$ Department of Animal Sciences, Faculty of Biological Sciences, Quaid-i-Azam

University, Islamabad, Pakistan

${ }^{3}$ Department of Community Health Sciences, College of Applied Medical

Sciences, King Saud University, Riyadh, Saudi Arabia

Full list of author information is available at the end of the article
}

(c) The Author(s). 2018 Open Access This article is distributed under the terms of the Creative Commons Attribution 4.0 International License (http://creativecommons.org/licenses/by/4.0/), which permits unrestricted use, distribution, and reproduction in any medium, provided you give appropriate credit to the original author(s) and the source, provide a link to the Creative Commons license, and indicate if changes were made. The Creative Commons Public Domain Dedication waiver (http://creativecommons.org/publicdomain/zero/1.0/) applies to the data made available in this article, unless otherwise stated. 


\section{Background}

Adverse treatment reactions due to antineoplastic agents are a common form of iatrogenic injury [1], which prevails mostly in an idiosyncratic and indiscriminate manner. Pulmonary toxicity initiated by antineoplastic drugs is becoming a more frequently documented entity. Continuous exploitation of combined modality therapies increased the prevalence of secondary lung tumors and its multiplicity [2]. The pathological situation is usually nonspecific but some histological evidences help define the underlying agent [3]. Several pharmacological mediators employed in the cure of cancer have been associated with pulmonary toxicity. Mechanisms of impairment by these drugs consist of either direct pulmonary toxicity or indirect action via boosting inflammatory reactions. Risk factors for expansion of pulmonary impairments have been elucidated for a few agents but remain unclear for others. Chronic pneumonitis/fibrosis is the most common clinical feature for most of the categories of cytotoxic drugs [4].

Cisplatin (cis-dichlorodiammineplatinum (II) CP) is a synthetic anticancer drug generally used for the treatment of several human malignancies [1-3]. Whilst, therapeutic use of $\mathrm{CP}$ encouraged oxidative trauma and DNA damage in various non-cancerous tissues as well e.g. kidney, liver, testis, brain, lungs etc. [5]. $\mathrm{CP}$ and its different analogs are identified to mutilate DNA by making covalent adducts. This interface is seemingly liable for the organ damage including the lungs. Investigations in various rodent models verified the mutagenic and tumorigenic effects of $\mathrm{CP}$. A single drug exposure produced skin and lung tumors in mice and rats, respectively [6]. CP is an effective therapeutic for lung cancer whilst free platinum intercalates or intracalates in DNA, induces severe injuriousness in experimental animals [2]. Cisplatin chemotherapy induced interstitial inflammation, fibrosis and structural lung damage associated with oblitrative bronchitis and increase perioperative complications in patients [7]. Pratibah and colleagues reported that $\mathrm{CP}$ administration for 18 weeks outcomes in pulmonary adenomas in $\mathrm{A} / \mathrm{J}$ mice, although the mechanism behind this tumor promotion is not well understood. CP mediated pathogenesis of lung might be attributed to the reduced antioxidant defense, increase lipid peroxidation and ROS production [8]. The role of ROS in pulmonary impairment is further reinforced by the increased activity of free radical quenching enzymes in lungs confronted by a variety of toxins [9]. Despite various endeavors, the adverse effects associated with $\mathrm{CP}$ remains a key reason that confines its usage and potency in cancer therapy.

Treatment with antioxidants ameliorates or reduces the advancement of lung ailments i.e., in patients with COPD, lung cancer, asthma and acute respiratory distress syndrome (ARDS). Moreover, diet containing fruits and vegetables rich in flavonoids and other antioxidant compounds could be responsible for prevention of cancer and persuasive in ameliorating chemotherapeutic drugs prompted toxicity [10-12]. Adjuvant therapies that enhance the anti-tumor effects of cisplatin are actively being pursued. Globally the inquisitiveness for alternative and complementary medicines has gained much attention because of the chemo-preventive and therapeutic significance of medicinal plants in controlling of several oxidative stress-induced disorders [13-15]. Innumerable plant-derived metabolites like genistein, curcumin, resveratrol, indole-3-carbinol, epigallocatechin gallate (EGCG), and proanthocyanidin are capable to enhance efficacy and reduce harmful effects of traditional chemotherapeutic agents [16]. It is of essential requirements that therapeutic plants should be explored for their medicinal attributes; for the reason that most of the people in undeveloped countries' practices alternative and complimentary medicines [17-19]. Genus Acacia possess species with diverse pharmacological properties, has come under extensive investigations in light of their anti-inflammatory, antitumor [20], antioxidant [21], wound healing [22], chemopreventive and antimutagenic [23] actions in various animal models [24]. Acacia hydaspica R. Parker synonym A. eburnea [25] belongs to family leguminosae is therapeutically important plant. The plant is normally used as fodder $[25,26]$ and is locally employed as antiseptic. In our previous lab experiments we revealed antioxidant, anti-cancer, anti-hemolytic, anti-inflammatory, antidepressant, and anxiolytic proficiencies of A. hydaspica [2730]. Various bioactive metabolites were detected in $A$. hydaspica i.e., 1,2-Benzenedicarboxylic acid mono (2-ethylhexyl) ester, $\alpha$-Amyrin, 2,6-dimethyl-N-(2-methyl-à-phenylbenzyl) aniline, Vitamin E, and Squalene, gallic acid, rutin, catechin, caffeic acid. Ethyl acetate fraction (AHE) of A. hydaspica showed excellent antioxidant activity in vitro. 7-O-galloyl catechin, +catechin and methyl gallate are the main bioactive metabolites with anticancer potential against breast and prostate cancer [27-29]. Various species of genus Acacia were reported for their antioxidant and protective potentials against lung toxicity in animal models [31]. A. hydaspica AHE fraction showed significant hepato-protective potential against cisplatin persuaded hepatic damage in rats [32]. Shahid and colleagues reported the protective potential of methanolic extract of Acacia catechu Willd bark. (MEBA) against the lung toxicity induced by $\mathrm{B}(\mathrm{a}) \mathrm{P}$ in mice. Pretreatment with MEBA at two different doses (200 and $400 \mathrm{mg} / \mathrm{kg}$ body weight) significantly ameliorates $\mathrm{B}(\mathrm{a}) \mathrm{P}$-induced increased toxicity markers and activities of detoxifying enzymes along with the levels of glutathione content. It also significantly attenuated expression of apoptotic and inflammatory markers in 
the lungs and attenuated destruction of alveolar architecture and necrosis of the alveolar epithelium of the lungs [33]. Acacia honey ameliorated sodium arsenide persuaded oxidative trauma in the cardiac, pulmonary, and renal tissues of rats due to its antioxidant potential and polyphenol components [34]. Nikbakht et al. indicated that Gallic acid protect lungs from bleomycin induced increased in inflammatory or fibrotic changes, collagen content, levels of malondialdehyde (MDA), and pro-inflammatory cytokines such as TNF- $\alpha$ and IL1 $\beta$. Furthermore Gallic acid reverse histological alterations and significantly increased non-enzymatic (total thiol) and enzymatic (glutathione peroxidase (GPx) antioxidant contents in the bleomycin treated rats' lung tissue by its antioxidant properties [35]. Gallic acid inhibit oxidative damaged to DNA in lymphocytes, liver, colon and lungs of rats [36]. The development of secondary malignancy as a result of $\mathrm{CP}$ chemotherapy can be also prevented with polyphenol treatment as indicated by the study of Mimoto et al. illustrating that Epigallocatechin Gallate (ECGC) inhibit CP prompted pulmonary tumorigenesis and weight diminution in A/J mice [2,37].

In view of protective potential of related Acacia species and polyphenolic compounds in animal models along with antioxidant and pharmacological activities of $A$. hydaspica. The present investigation aimed to find out the healing effect of AHE against CP-induced oxidative trauma and DNA injury in pulmonary tissue of rats via biochemical, DNA ladder assay and histopathological approaches.

\section{Methods}

\section{Plant collection and preparation of AHE extract}

A. hydaspica aerial parts were picked up from Kirpa charah area Islamabad, Pakistan. Plant sample was recognized by Dr. Sumaira Sahreen (Curator at Herbarium of Pakistan, Museum of Natural History, Islamabad) and voucher specimen (Accession No. 0642531) was submitted at the Herbarium of Pakistan, Museum of Natural History, Islamabad. A. hydaspica methanol extract was fractionated as previously described [30], and its ethyl acetate extract (AHE) (the fraction with maximum bioactivity was tested for protective proficiency against $\mathrm{CP}$ induced toxicity.

\section{Sample preparation}

Cisplatin (CP) (Sigma-Aldrich, St. Louis, MO, U.S.A.) was diluted in saline to make accurate dose for testing. $7.5 \mathrm{mg} / \mathrm{kg}$ body weight dose of CP was selected on the basis of previous literature to induce acute renal toxicity [38]. Silymarin (100 mg/kg b.w) and AHE $(400 \mathrm{mg} / \mathrm{kg}$ b.w) were prepared freshly in distilled water before treating.

\section{Acute toxicity evaluation}

The acute toxicity study was conducted as per the guidelines 425 of Organization for Economic Cooperation and Development (OECD) for testing of chemicals for acute oral toxicity [39]. The detailed procedure is described in our earlier research [32]. General behavioral changes were detected by the previously described procedure [40]. Animals were observed continuously for $2 \mathrm{~h}$ and parameters which were observed were convulsion, tremor, aggression, excitation, loss of grasp, altered reactivity to touch, and sedation [41]. AHE was proved to be harmless at all tested quantities (up to $4000 \mathrm{mg} / \mathrm{kg}$ b.w) and it did not persuaded any noxious symptom in rats like sedation, convulsions, diarrhea and irritation. $400 \mathrm{mg} / \mathrm{kg}$ bw dose was selected for further in vivo evaluation.

\section{Experimental design}

Thirty six male Sprague Dawley rats (200-225 g) were kept in the Primate Facility at Quaid-i-Azam University, Islamabad. The animals were placed in conventional steel cages at room temperature, fed with standard pellet diet and tap water under $12 \mathrm{~h}$ light/dark cycle at $25 \pm 3^{\circ}$ C. Guidelines of national institute of animal health $(\mathrm{NIH}$ guidelines) were strictly adapted in order to conduct the experiment effectively. The experimental protocol (Bch\#264) was approved ethical board of Quaid-i-Azam University, Islamabad. The investigational was planned according to earlier studies [42, 43] with trivial modifications. Animals were distributed into six groups $(n=6)$.

The following treatment procedure was adopted for the study.

Group I: Control; received distilled water.

Group II: CP treated; received single dose of $\mathrm{CP}$ (7.5 mg/kg b.w., i.p.).

Group III: AHE treated; received oral dose $(400 \mathrm{mg} / \mathrm{kg}$ b.w) of AHE for 1 week.

Group IV: CP + AHE (Post-treated); administered AHE (400 mg/kg b.w/day, p.o.) for 1 week after CP injection [44].

Group V: AHE + CP (pretreated); received AHE ( $400 \mathrm{mg} / \mathrm{kg}$ body weight/day, p.o) for 1 week before CP (7.5 mg/kg b.w., i.p.).

Group VI: Sily+CP; received silymarin $(100 \mathrm{mg} / \mathrm{kg}$ b.w., p.o) for 1 week before CP (7.5 mg/kg b.w., i.p.).

Male rats were chosen for study because they have persistent metabolism in contrast to females. Body weights of rats were note down at the start and completion of the experiment. The rats were humanly sacrificed by decapitation under light ether anesthesia. The lungs were removed, and rinsed with ice cold saline and dried with blotting paper, and weighted. Subsequently, half of the organs were preserved in liquid nitrogen and stored at $-80{ }^{\circ} \mathrm{C}$ for further enzymatic and DNA damage 
examination whereas the other portion was stored in 10\% phosphate buffered formalin for histological analysis.

\section{Biochemical analysis Homogenate preparation}

Pulmonary tissue sample (100 mg) was homogenized in 10 volume of $100 \mathrm{mM} \mathrm{KH} \mathrm{PO}_{4}$ buffer including $1 \mathrm{mM}$ EDTA, pH 7.4. The homogenate was centrifuged at $12000 \times \mathrm{g}$ for $30 \mathrm{~min}$ at $4{ }^{\circ} \mathrm{C}$ and the supernatant was set aside in aliquots and put in storage at $-20{ }^{\circ} \mathrm{C}$ for examination of antioxidant enzymes, lipid peroxidation products, $\mathrm{H}_{2} \mathrm{O}_{2}$ and nitrite content.

\section{Estimation of tissue protein content}

The entire soluble proteins within the tissue homogenate were estimated as described earlier [45]. Tissue sample (100 mg) was homogenized in potassium phosphate buffer and centrifuged at $4{ }^{\circ} \mathrm{C}$ at $10000 \times \mathrm{g}$ for $15-20 \mathrm{~min}$ to attain the supernatant. To the supernatant $(0.1 \mathrm{ml})$ $1 \mathrm{ml}$ of alkaline solution was poured and then vortexed. The mixture was incubated for $30 \mathrm{~min}$ and change in absorbance was observed at $595 \mathrm{~nm}$. The concentration of protein in the sample was estimated using bovine serum albumin (BSA) standard calibration.

\section{Enzymatic antioxidant status Catalase (CAT) activity}

The CAT activity was estimated as described previously [46]. The CAT reaction solution consists of $35 \mu \mathrm{l} \mathrm{hom-}$ ogenate, $625 \mu$ l of $50 \mathrm{mM}$ of potassium phosphate buffer (pH 5), $100 \mu \mathrm{l}$ of $5.9 \mathrm{mM} \mathrm{H} \mathrm{H}_{2}$. Change in the absorbance of the reaction solution was noted after $1 \mathrm{~min}$ at $240 \mathrm{~nm}$. An absorbance change of 0.01 as units $/ \mathrm{min}$ denotes one unit of catalase activity.

\section{Peroxidase (POD) activity}

POD enzyme activity was tested by previously defined procedure with slight modifications [46]. POD reaction solution contains $20 \mathrm{mM}$ guaiacol $(25 \mu \mathrm{l}), 40 \mathrm{mM}$ hydrogen peroxide $(75 \mu \mathrm{l}), 625 \mu \mathrm{l}$ of $50 \mathrm{mM}$ potassium phosphate buffer ( $\mathrm{pH}$ 5.0) and $25 \mu \mathrm{l}$ of tissue homogenate. Subsequently change in absorbance was determined at $470 \mathrm{~nm}$ after $1 \mathrm{~min}$ wait. One unit POD activity is equivalent to change in absorbance of 0.01 as units $/ \mathrm{min}$.

\section{Superoxide dismutase (SOD) activity}

The assessment of SOD activity was done by following Kakkar et al. method [47]. Tissue homogenate was centrifuge at $1500 \times \mathrm{g}$ for $10 \mathrm{~min}$ and then at $10,000 \times \mathrm{g}$ for $15 \mathrm{~min}$. Supernatant was collected and $150 \mu \mathrm{l}$ of supernatent was added to the aliquot containing $600 \mu \mathrm{l}$ of $0.052 \mathrm{mM}$ sodium pyrophosphate buffer ( $\mathrm{pH} 7.0$ ) and $186 \mathrm{mM}$ of phenazine methosulphate $(50 \mu \mathrm{l})$. To initiate enzymatic reaction $100 \mu \mathrm{l}$ of $780 \mu \mathrm{M}$ NADH was added.
After $1 \mathrm{~min}$, glacial acetic acid $(500 \mu \mathrm{l})$ was added to stop the reaction. At $560 \mathrm{~nm}$ optical density was determined to enumerate the color intensity. Results were calculated in units/mg protein.

\section{Quinone reductase assay (QR)}

The Quinone reductase activity in pulmonary tissue samples was evaluated as described later [48]. Reaction mixture $(3 \mathrm{ml})$ included $25 \mathrm{mM}$ Tris- $\mathrm{HCl}$ buffer $(2.13 \mathrm{ml}$; $\mathrm{pH} 7.4), 700 \mu \mathrm{l}$ of BSA, $100 \mu \mathrm{l}$ of FAD, $20 \mu \mathrm{l}$ of $0.1 \mathrm{mM}$ $\mathrm{NADPH}$ and $100 \mu \mathrm{l}$ of pulmonary tissue homogenate. Reduction of dichlorophenolindophenol (DCPIP) was noted at $600 \mathrm{~nm}$. Enzyme potency was estimated as $\mathrm{nM}$ of DCPIP reduced $/ \mathrm{min} / \mathrm{mg}$ protein by employing molar extinction coefficient of $2.1 \times 10^{4} / \mathrm{M} / \mathrm{cm}$.

\section{Reduced glutathione (GSH) assay}

Reduced glutathione activity was tested as described by Jollow [49]. $500 \mu \mathrm{l}$ of $4 \%$ sulfosalicylic acid was used for the precipitation of tissue homogenate. Subsequently $1 \mathrm{~h}$ of incubation at $4{ }^{\circ} \mathrm{C}$ all samples were centrifuged for $20 \mathrm{~min}$ at $1200 \times \mathrm{g}$. $33 \mu \mathrm{l}$ supernatant was added to aliquots consisting of $900 \mu \mathrm{l}$ of $0.1 \mathrm{M}$ potassium phosphate buffer (pH 7.4) and $66 \mu \mathrm{l}$ of $100 \mathrm{mM}$ DTNB. Reaction of GSH with DTNB produced a yellow colored complex which was estimated at $412 \mathrm{~nm}$. The GSH activity was presented as $\mu \mathrm{M}$ GSH/g tissue.

\section{Glutathione-S-transferase (GST)}

Scheme of Habig et al. [50] was applied for the assessment of GST. $150 \mu \mathrm{l}$ aliquot of tissue homogenate was added to $720 \mu \mathrm{l}$ of sodium phosphate buffer together with $100 \mu \mathrm{l}$ of reduced glutathione $(1 \mathrm{mM})$ and $12.5 \mu \mathrm{l}$ of $\mathrm{CDNB}$ (1 mM). Optical density was recorded at $340 \mathrm{~nm}$ by spectrophotometer. GST activity was estimated through molar coefficient of $9.61 \times 10^{3} / \mathrm{M} / \mathrm{cm}$ as amount of $\mathrm{CDNB}$ conjugate formed per minute per mg protein.

\section{Glutathione reductase assay (GR)}

Glutathione reductase activity in tissue samples was examined as described by Carlberg and Mannervik [51]. The reaction reagent $(2 \mathrm{ml})$ contained $1.65 \mathrm{ml}$ phosphate buffer $(0.1 \mathrm{M} ; \mathrm{pH}$ 7.6), $100 \mu \mathrm{l}$ EDTA $(0.5 \mathrm{mM}), 50 \mu \mathrm{l}$ oxidized glutathione $(1 \mathrm{mM}), 100 \mu \mathrm{l}$ NADPH $(0.1 \mathrm{mM})$ and $100 \mu \mathrm{l}$ of homogenate. Activity of enzyme was monitered by recording the absorbance of the vanishing of NADPH at $340 \mathrm{~nm}$ at $25^{\circ} \mathrm{C}$. Enzyme level was estimated as nM NADPH oxidized/ $\mathrm{min} / \mathrm{mg}$ protein by employing molar extinction coefficient of $6.22 \times 10^{3} / \mathrm{M} / \mathrm{cm}$.

\section{Glutathione peroxidase assay (GPX)}

Glutathione peroxidase activity was calculated as defined earlier [52]. Entire volume of $2 \mathrm{ml}$ reaction solution 
comprised of $1 \mathrm{mM}$ EDTA $(100 \mu \mathrm{l}), 0.1 \mathrm{M}$ phosphate buffer (1.49 ml; pH 7.4), $1 \mathrm{~m} \mathrm{M}$ sodium azide $(100 \mu \mathrm{l})$, $1 \mathrm{IU} / \mathrm{ml}$ glutathione reductase $(50 \mu \mathrm{l}), 1 \mathrm{mM}$ GSH $(50 \mu \mathrm{l}), 0.2 \mathrm{mM} \mathrm{NADPH}(100 \mu \mathrm{l}), 0.25 \mathrm{mM} \mathrm{\textrm {H } _ { 2 } \mathrm { O } _ { 2 }}$ $(10 \mu \mathrm{l})$ and tissue homogenate $(100 \mu \mathrm{l})$. The loss of $\mathrm{NADPH}$ was recorded at $340 \mathrm{~nm}$ at room temperature. Enzyme level was assessed as nM NADPH oxidized/ $\mathrm{min} / \mathrm{mg}$ protein employing $6.22 \times 10^{3} / \mathrm{M} / \mathrm{cm}$ molar extinction coefficient.

\section{$\gamma$-Glutamyl transpeptidase $(\gamma-G T)$}

The activity of $\gamma$-glutamyl transpeptidase was tested via Orlowski et al. scheme [53]. Reaction solution consist of an aliquot of $50 \mu \mathrm{l}$ tissue homogenate, $250 \mu \mathrm{l}$ of glutamyl nitroanilide $(4 \mathrm{mM}), 250 \mu \mathrm{l}$ of glycyl glycine $(40 \mathrm{mM})$ and $250 \mu \mathrm{l}$ of $\mathrm{MgCl} 2(11 \mathrm{mM})$ which was primed with $185 \mathrm{mM}$ Tris $\mathrm{HCl}$ buffer at room temperature. After 10 min of incubation, the reaction was stopped with the addition of $250 \mu \mathrm{l} 25 \%$ trichloro acetic acid. Then centrifugation was done at $2500 \times \mathrm{g}$ for $10 \mathrm{~min}$ and optical density was determined at $405 \mathrm{~nm}$. Activity of $\gamma$-GT was determined as $\mathrm{nM}$ nitroaniline formed per min per $\mathrm{mg}$ protein by using molar extinction coefficient of $1.75 \times$ $10^{3} / \mathrm{M} / \mathrm{cm}$.

\section{Oxidative stress markers \\ Lipid peroxidation assay (MDA content)}

Protocol of Iqbal et al. [54] was implemented with trivial adjustments for the valuation of tissue lipid peroxidation. The reaction mixture consists of $0.1 \mathrm{M}$ phosphate buffer of $290 \mu \mathrm{l}$ (pH 7.4), $100 \mathrm{mM}$ ferric chloride $(10 \mu \mathrm{l})$, $100 \mathrm{mM}$ ascorbic acid $(100 \mu \mathrm{l})$ and $100 \mu \mathrm{l}$ of homogenized sample. Incubation of the mixture was completed in shaking water bath for $1 \mathrm{~h}$ at $37{ }^{\circ} \mathrm{C}$. Subsequently $10 \%$ trichloroacetic acid $(500 \mu \mathrm{l})$ was added to stop the reaction. Afterwards $0.67 \%$ thiobarbituric acid $(500 \mu \mathrm{l})$ was decanted and the reaction tubes were remained for $20 \mathrm{~min}$ in the water bath. Then all the reaction tubes were put on crushed ice bath for 5 min followed by centrifugation at $2500 \times \mathrm{g}$ for $12-15 \mathrm{~min}$. By spectrophotometer absorbance was calculated at $535 \mathrm{~nm}$. By exploiting the molar extinction coefficient of $1.56 \times 10^{5} / \mathrm{M} / \mathrm{cm}$. Outcomes were assessed as nM of TBARS generates per min per mg tissue at $37^{\circ} \mathrm{C}$.

\section{Hydrogen peroxide assay}

Hydrogen peroxide activity in tissue samples was examined by scheme described previously [55]. In the reaction mixture, $500 \mu \mathrm{l}$ of $0.05 \mathrm{M}$ phosphate buffer ( $\mathrm{pH} 7$ ), $100 \mu \mathrm{l}$ of homogenate was added along with $100 \mu \mathrm{l}$ of $0.28 \mathrm{nM}$ phenol red solution, $250 \mu \mathrm{l}$ of $5.5 \mathrm{nM}$ dextrose and horse radish peroxidase (8.5 units) was added. Incubation was completed at room temperature for 60 min. $100 \mu \mathrm{l}$ of $\mathrm{NaOH}(10 \mathrm{~N})$ was added to stop the reaction. Then mixture tubes were centrifuged for $5-10 \mathrm{~min}$ at $800 \times \mathrm{g}$. The absorbance of the supernatant was calculated against reagent blank at $610 \mathrm{~nm}$. Production of $\mathrm{H}_{2} \mathrm{O}_{2}$ was measured as $\mathrm{nM} \mathrm{H}_{2} \mathrm{O}_{2} / \mathrm{min} / \mathrm{mg}$ tissue by employing the standard curve of phenol red oxidized by $\mathrm{H}_{2} \mathrm{O}_{2}$.

\section{Nitrite assay}

Griess reagent was employed for the accomplishment of nitrite assay [56]. Briefly, tissue samples (100 mg each) were de-proteinised in $100 \mu \mathrm{l}$ solution consist of $5 \%$ $\mathrm{ZnSO}_{4}$ and $0.3 \mathrm{M} \mathrm{NaOH}$. Samples were Centrifuge at $6400 \times \mathrm{g}$ for $15-20 \mathrm{~min} .20 \mu \mathrm{l}$ of supernatant was poured in a cuvette having $1 \mathrm{ml}$ of Griess reagent, alteration in color was observed at $540 \mathrm{~nm}$. Griess reagent $1 \mathrm{ml}$ was used as a blank in the spectrophotometer (Smart Spec TM Spectrophotometer). Standard curve of sodium nitrite was utilized for the quantification nitrite concentration in tissues.

\section{DNA damage analysis DNA fragmentation assay with diphenylamine reaction} Wu et al. [26] protocol was adopted for analysis of DNA fragmentation in pulmonary tissues. $100 \mathrm{mg}$ tissue was homogenized in TTE solution. $100 \mu \mathrm{l}$ of tissue homogenate (labeled B) was centrifuged at $200 \times \mathrm{g}$ for $10 \mathrm{~min}$ at $4{ }^{\circ} \mathrm{C}$ and supernatant was collected and labeled $\mathrm{S}$. subsequently the $\mathrm{S}$ tubes were centrifuged at $20,000 \times \mathrm{g}$ at $4{ }^{\circ} \mathrm{C}$ for $10 \mathrm{~min}$ to separate intact chromatin and this was labeled as T. Next $1.0 \mathrm{ml}$ of $25 \%$ TCA was pipetted in all tubes i.e., $\mathrm{T}, \mathrm{B}$, and $\mathrm{S}$, and leave for overnight at $4^{\circ}$ C. After incubation samples were pelleted for $10 \mathrm{~min}$ at $18,000 \times \mathrm{g}$ at $4{ }^{\circ} \mathrm{C}$ to recover the precipitated DNA. $160 \mu \mathrm{l}$ of $5 \%$ TCA was added to each pellet and heated for $15 \mathrm{~min}$ at $90{ }^{\circ} \mathrm{C}$ then $320 \mu \mathrm{l}$ of freshly made DPA solution was poured, vortexed and incubated for $4 \mathrm{~h} 37^{\circ}$ C. Optical density of samples was read at $600 \mathrm{~nm}$ with a spectrophotometer (Smart spec TM Plus, catalog \# 170-2525).

\section{DNA isolations and ladder assay}

DNA isolation was performed by the methods of Wu et al. [26]. Tissue sample $(100 \mathrm{mg})$ was placed in petri dishes and rinse with DNA Buffer and homogenized in $1 \mathrm{ml}$ lysis buffer. Add $100 \mu \mathrm{l}$ of proteinase $\mathrm{K}(10 \mathrm{mg} / \mathrm{ml})$ and $240 \mu 10 \%$ SDS in homogenized mixture and agitated slightly. Next the mixture was incubated overnight at $45{ }^{\circ} \mathrm{C}$ in a water bath then $0.4 \mathrm{ml}$ of phenol was added and agitated for 5-10 min before centrifugation at $3000 \mathrm{rpm}$ for $5 \mathrm{~min}$ at $10{ }^{\circ} \mathrm{C}$. Supernatant was mixed with $1.2 \mathrm{ml}$ phenol and $1.2 \mathrm{ml}$ Chloroform/isoamyl alcohol (24:1) and shake for 5-10 min before centrifugation at $3000 \mathrm{rpm}$ for $5 \mathrm{~min}$ at $10{ }^{\circ} \mathrm{C}$. $25 \mu \mathrm{l}$ of sodium acetate $(\mathrm{pH} 5.2,3 \mathrm{M})$ and $5 \mathrm{ml}$ ethanol was added to 
supernatant and agitated until DNA was precipitated. DNA was washed with $70 \%$ ethanol and then clean DNA was liquefied in TE buffer. The DNA concentration was checked at 260 and $280 \mathrm{~nm} .5 \mu \mathrm{g}$ of samples DNA and $0.5 \mu \mathrm{g}$ DNA standard was loaded on $1.5 \%$ agarose gel containing ethidium bromide. Electrophoresis was performed for $45 \mathrm{~min}$ at $100 \mathrm{~V}$ batteries, and DNA was observed under digital gel doc system and photographed.

\section{Histopathological investigation}

Pulmonary tissues from each group were fixed in a fixative containing absolute alcohol $(85 \mathrm{ml})$, glacial acetic acid $(5 \mathrm{ml})$ and $40 \%$ formaldehyde $(10 \mathrm{ml})$. After dehydration tissue samples were fixed in parafilm to prepare blocks for microtomy. Tissues were sectioned 4-5 $\mu \mathrm{m}$ with microtome and stained with Hemotoxilin-Eosin $(H \& E)$ and inspected under light microscope (DIALUX $20 \mathrm{~EB})$ at $40 \mathrm{X}$.

\section{Statistical analysis}

Data are expressed mean \pm SEM $(n=6)$. The statistical changes between different treatment groups was calculated by One way analysis of variance (ANOVA) followed by Tukey's test using Graph pad prism 5 software. Level of significance was set at $p<0.05$.

\section{Results}

\section{Estimation of acute toxicity}

AHE was revealed innocuous at all tested doses (up to $4000 \mathrm{mg} / \mathrm{kg}$ ) and no appearance of any noxious symptom in rats like sedation, convulsions, diarrhea, and irritation was noticed. Throughout the 7 days of the valuation, no mortality was observed. Therefore, one tenth of the maximum dose, $400 \mathrm{mg} / \mathrm{kg}$ b.w. was used for the in vivo valuation of AHE.

\section{General toxicity}

The rats treated with cisplatin, AHE alone or cisplatin+ AHE did not show any clinical signs of toxicity (such as unusual salivation, flicking movements, shiver, head and forelimb clonuses, spasms, incoordination, diarrhea, increased diuresis). No death was witnessed in both treated and untreated groups of rats during the experimental period.

\section{Body and organ weights}

The effect of AHE treatment before and after CP intoxication on the body and Lung tissue weight is reported in Table 1. Data revealed significant $(p<0.001)$ fall in the final body weights of $\mathrm{CP}$ alone treated rats in comparison to both control and AHE treatment groups. Both pre and post treatments with AHE results in significant elevation in the final body weight of CP treated animals,
Table 1 Effect of cisplatin and/or AHE treatment on body weight and lung weight of rats

\begin{tabular}{llll}
\hline Group & \multicolumn{2}{l}{ Body weight $(\mathrm{g})$} & Lung weight \\
\cline { 2 - 3 } & Initial & Final & \\
\hline Control & $218.3 \pm 0.882$ & $259.7 \pm 0.667^{\mathrm{b}}$ & $0.709 \pm 0.01^{\mathrm{b}}$ \\
CP & $220.0 \pm 0.577$ & $226.3 \pm 0.66^{\mathrm{a}}$ & $0.971 \pm 0.03^{\mathrm{a}}$ \\
AHE alone & $218.0 \pm 0.577$ & $258.3 \pm 0.667^{\mathrm{b}}$ & $0.701 \pm 0.012^{\mathrm{b}}$ \\
$\mathrm{CP}+$ AHE & $220.3 \pm 0.881$ & $244.0 \pm 0.577^{\mathrm{a}, \mathrm{b}}$ & $0.839 \pm 0.021^{\mathrm{a}^{* *}, \mathrm{~b}^{* *}, \mathrm{c}^{*}}$ \\
AHE + CP & $219.0 \pm 0.576$ & $254.7 \pm 0.881^{\mathrm{a}, \mathrm{b}, \mathrm{c}}$ & $0.735 \pm 0.015^{\mathrm{b}}$ \\
CP + Sily & $218.7 \pm 0.667$ & $253.7 \pm 0.667^{\mathrm{a}, \mathrm{b}}$ & $0.737 \pm 0.022^{\mathrm{b}}$ \\
\hline
\end{tabular}

Data expressed as mean \pm SEM $(n=6)$. a: significant difference of final body weight of group Vs. Control group at $p<0.001$, b: significant difference of final body weight of group Vs. Cp-treated group at $p<0.001$, c: significant difference of final body weight of AHE + CP pre-treated group Vs. CP + AHE post-treated group at $p<0.001$. Sily; Silymarin. ${ }^{*}$ or ${ }^{* *}$ indicates significant difference at $\mathrm{p}<$ 0.05 and $p<0.001$ respectively

and pretreatment seems to be more effective $(p<0.001)$ in reducing the growth impeding effects of CP. Results indicated significant difference in the lung weights of $\mathrm{CP}$ treated rats and control rats. AHE treatment significantly ameliorated lung weight fluctuations in contrast to $\mathrm{CP}$ alone treated group.

\section{Protective effect of AHE on pulmonary enzymatic antioxidant status}

The protective effect of AHE against $\mathrm{CP}$ induced alterations in POD, SOD, CAT and QR, are shown in the Table 2. CP inoculation markedly $(p<0.0001)$ declined the tissue levels of SOD, POD, CAT and QR. Post and pre-treatment of AHE significantly attenuated the suppressed enzyme activity in $\mathrm{CP}$ injected groups as compared to the only $\mathrm{CP}$ treated group. Post-treatment with AHE did not enhance the activity of POD enzyme when compared to $\mathrm{CP}$ alone treated group while, significant increase in activity of SOD, CAT and QR was noticed. The Pre-treatment of rats with AHE before CP intoxication seems to be more effective in restoring the above mention enzymes levels as compared to post-treatment group.

Table 3 shows the protective effect of AHE against CP-induced deterioration on GSH, GR, GST, $\gamma$-GT and GPx profile in pulmonary tissues. Cisplatin single dose significantly decreased the levels of phase II antioxidant enzymes in comparison to control. Data indicates that AHE pre-treatment and silymarin completely restored the GSH levels similar to control. Pre administration of AHE before CP intoxication bring about more significant $(p<0.001)$ augmentation in GSH, GR, GST, $\gamma$-GT and GPx levels as compared to AHE post administration, indicating the protective effect of AHE against $\mathrm{CP}$ induced deteriorations. The protective effect of AHE pre-treatment against $\mathrm{CP}$ provoked pulmonary toxicity was comparable to silymarin. AHE when orally 
Table 2 Effect of cisplatin (CP) and different treatments of AHE on lungs tissue antioxidant enzymes and GSH profile

\begin{tabular}{llllll}
\hline Group & GSH $(\mu \mathrm{M} / \mathrm{g}$ tissue $)$ & $\mathrm{GR}(\mathrm{nM} / \mathrm{min} / \mathrm{mg}$ protein) & GST (nM/min/mg protein) & $\gamma$-GT (nM/min/mg Protein) & GPx (nM/min/mg Protein) \\
\hline Control & $16.12 \pm 0.578^{\mathrm{b}}$ & $143.7 \pm 1.342^{\mathrm{b}}$ & $98.85 \pm 0.918^{\mathrm{b}}$ & $295.4 \pm 1.113^{\mathrm{b}}$ & $107.4 \pm 0.730^{\mathrm{b}}$ \\
$\mathrm{CP}$ & $8.334 \pm 0.356^{\mathrm{a}}$ & $98.02 \pm 0.619^{\mathrm{a}}$ & $68.17 \pm 0.962^{\mathrm{a}}$ & $82.82 \pm 0.958^{\mathrm{a}}$ & $54.08 \pm 0.909^{\mathrm{a}}$ \\
AHE alone & $6.38 \pm 0.207^{\mathrm{b}}$ & $144.0 \pm 1.492^{\mathrm{b}}$ & $99.79 \pm 1.865^{\mathrm{b}}$ & $295.6 \pm 0.599^{\mathrm{b}}$ & $108.8 \pm 1.216^{\mathrm{b}}$ \\
$\mathrm{CP}+\mathrm{AHE}$ & $11.99 \pm 0.305^{\mathrm{a}, \mathrm{b}, \mathrm{d}}$ & $116.9 \pm 0.813^{\mathrm{a}, \mathrm{b}, \mathrm{d}}$ & $78.34 \pm 1.076^{\mathrm{a}, \mathrm{b}^{* *}, \mathrm{~d}^{* *}}$ & $137.8 \pm 1.017^{\mathrm{a}, \mathrm{b}, \mathrm{d}}$ & $71.28 .8 \pm 0.501^{\mathrm{a}, \mathrm{b}, \mathrm{c}}$ \\
$\mathrm{AHE}+\mathrm{CP}$ & $15.63 \pm 0.532^{\mathrm{b}, \mathrm{c}}$ & $135.0 \pm 0.393^{\mathrm{a}, \mathrm{b}, \mathrm{c}}$ & $89.65 \pm 1.49^{\mathrm{a} *, \mathrm{~b}, \mathrm{c}}$ & $261.4 \pm 0.802^{\mathrm{a}, \mathrm{b}, \mathrm{c}}$ & $92.78 \pm 1.216^{\mathrm{a}, \mathrm{b}, \mathrm{c}}$ \\
$\mathrm{CP}+$ Sily & $15.29 \pm 0.312^{\mathrm{b}}$ & $133.8 \pm 1.25^{\mathrm{a}, \mathrm{b}}$ & $87.60 \pm 1.644^{\mathrm{a}, \mathrm{b}}$ & $264.3 \pm 1.067^{\mathrm{a}, \mathrm{b}}$ & $95.64 \pm 1.573^{\mathrm{a}, \mathrm{b}}$
\end{tabular}

Values expressed as mean \pm SEM. a: Significance at $p<0.0001$ Vs. control group, b: Significance at $p<0.0001$ Vs. Cisplatin (CP) group. c: Significance at $p<0.0001$ of $\mathrm{AHE}+\mathrm{CP}$ pre-treated group Vs. CP + AHE post-treated group. d: Significance at $p<0.0001$ of CP + AHE treatment groups Vs CP + Sily group. ${ }^{*}$, $:$ Significant difference at $p<0.05$ and $p<0.001$ respectively. Non-significant difference $(p>0.05)$ was recorded between control and AHE alone treated group in all parameters (One way ANOVA followed by Tukey's multiple comparison tests)

administered alone, showed non-significant change in the level of above mentioned antioxidant enzymes compared to control. The protective effect of AHE may be mediated via modulation of enzyme systems via reducing the generation of free radicals.

\section{Protective effect of AHE against CP induced oxidative stress and lipid peroxidation}

Oxidative stress owing to shift in the balance between oxidants and antioxidants in support of oxidants via decreasing the antioxidant capacity. $\mathrm{H}_{2} \mathrm{O}_{2}$ and nitrite (NO) level are considered to be an important indicator of oxidative stress. Malonyldialdehyde (MDA) is being one of the overwhelming products resulting from lipid peroxidation with recognized effect on the level of the human genome and is considered as clastogenic and genotoxic agent. Hence the amount of MDA in the biological sample can be measured as a sign of increased lipid peroxidation, therefore, an indicator of oxidative injury in vivo. The effect of $\mathrm{AHE}$ and $\mathrm{CP}$ on lung tissue protein, $\mathrm{H}_{2} \mathrm{O}_{2}$, NO and lipid peroxidation product (MDA) formation is given in the Table 4. Protein content in CP alone treated group decreased significantly; AHE post and pre-treatments ameliorated the toxic effect of CP. AHE pre-treatment restored the protein content relative to the control group, and enhanced $(p<0.001)$ protein content relative to AHE posttreatment group.

The oxidative stress markers $\left(\mathrm{H}_{2} \mathrm{O}_{2}\right.$ and $\left.\mathrm{NO}\right)$ were significantly raised in the $\mathrm{CP}$ treated group which were decreased significantly $(p<0.0001)$ with AHE pretreatment. Similarly the MDA level was increased significantly $(p<0.0001)$ by CP treatment and diminished considerably $(p<0.001$ and $p<0.0001)$ by both AHE post and Pre-treatments respectively, while pre-treatment was recorded to be more significant $(p<0.0001)$ in reducing the lipid peroxidation compared to post treatment group. AHE pre-treatment minimized the MDA content and the levels were similar to that of control and silymarin treated group. AHE treatment alone at $400 \mathrm{mg} / \mathrm{kg} \mathrm{b.w}$ showed no alteration in protein content, oxidative stress markers and lipid peroxidation when compared to control.

\section{Molecular studies for analysis of DNA damage Percent DNA fragmentation}

DNA fragmentation (\%) showed marked changes in all experimental groups (Fig. 1 a). The AHE treated groups repaired the DNA damage induced by $\mathrm{CP}$ and decreased the DNA fragmentation showing the protective effects at the genetic level. Pre-administration of AHE reversed

Table 3 Effect of cisplatin (CP) and different treatments of AHE on lung tissue protein, oxidative stress markers and lipid peroxidation

\begin{tabular}{lllll}
\hline Group & Protein $(\mu \mathrm{g} / \mathrm{mg}$ Tissue $)$ & $\mathrm{H}_{2} \mathrm{O}_{2}(\mathrm{nM} / \mathrm{min} / \mathrm{mg}$ Tissue) & Nitrite $($ content $\mu \mathrm{M} / \mathrm{ml})$ & $\mathrm{MDA}(\mathrm{nM} / \mathrm{min} / \mathrm{mg}$ protein) \\
\hline Control & $1.722 \pm 0.042^{\mathrm{b}}$ & $2.192 \pm 0.025^{\mathrm{b}}$ & $44.59 \pm 0.609^{\mathrm{b}}$ & $3.66 \pm 0.265^{\mathrm{b}}$ \\
$\mathrm{CP}$ & $0.965 \pm 0.072^{\mathrm{a}}$ & $5.752 \pm 0.081^{\mathrm{a}}$ & $82.16 \pm 1.531^{\mathrm{a}}$ & $8.649 \pm 0.403^{\mathrm{a}}$ \\
AHE lone & $1.711 \pm 0.056^{\mathrm{b}}$ & $2.148 \pm 0.034^{\mathrm{b}}$ & $44.26 \pm 0.385^{\mathrm{b}}$ & $3.599 \pm 0.245^{\mathrm{b}}$ \\
$\mathrm{CP}+$ AHE & $1.237 \pm 0.025^{\mathrm{a}, \mathrm{b}^{*}, \mathrm{~d}^{* *}}$ & $4.498 \pm 0.073^{\mathrm{a}, \mathrm{b}, \mathrm{d}}$ & $68.14 \pm 0.81^{\mathrm{a}, \mathrm{b}, \mathrm{d}}$ & $6.965 \pm 0.214^{\mathrm{a}, \mathrm{b}^{* *, d}}$ \\
$\mathrm{AHE}+\mathrm{CP}$ & $1.582 \pm 0.040^{\mathrm{b}, \mathrm{c}^{* *}}$ & $3.049 \pm 0.136^{\mathrm{a}, \mathrm{b}, \mathrm{c}}$ & $50.53 \pm 0.410^{\mathrm{a}^{*}, \mathrm{~b}, \mathrm{c}}$ & $4.614 \pm 0.184^{\mathrm{b}, \mathrm{c}}$ \\
$\mathrm{CP}+$ Sily & $1.591 \pm 0.075^{\mathrm{b}}$ & $2.99 \pm 0.012^{\mathrm{a}, \mathrm{b}}$ & $50.03 \pm 1.149^{\mathrm{a}^{*}, \mathrm{~b}}$ & $4.396 \pm 0.208^{\mathrm{b}}$ \\
\hline
\end{tabular}

Values expressed as mean \pm SEM. a: Significance at $p<0.0001$ Vs. control group, b: Significance at $p<0.0001$ Vs. Cisplatin (CP) group. C: Significance at $p<0.0001$ of $\mathrm{AHE}+\mathrm{CP}$ pre-treated group Vs. CP + AHE post-treated group. d: Significance at $p<0.0001$ of CP + AHE treatment groups Vs CP + Sily group. ${ }^{*}$, ${ }^{* *}:$ Significant difference at $p<0.05$ and $p<0.001$ respectively. Non-significant difference $(p>0.05)$ was recorded between control and AHE alone treated group in all parameters (One way ANOVA followed by Tukey's multiple comparison tests) 
Table 4 Effect of cisplatin (CP) and different treatments of AHE on lung tissue protein, oxidative stress markers and lipid peroxidation

\begin{tabular}{lllll}
\hline Group & Protein $(\mu \mathrm{g} / \mathrm{mg}$ Tissue $)$ & $\mathrm{H}_{2} \mathrm{O}_{2}(\mathrm{nM} / \mathrm{min} / \mathrm{mg}$ Tissue $)$ & Nitrite (content $\mu \mathrm{M} / \mathrm{ml})$ & $\mathrm{MDA}(\mathrm{nM} / \mathrm{min} / \mathrm{mg}$ protein) \\
\hline Control & $1.722 \pm 0.042^{\mathrm{b}}$ & $2.192 \pm 0.025^{\mathrm{b}}$ & $44.59 \pm 0.609^{\mathrm{b}}$ & $3.66 \pm 0.265^{\mathrm{b}}$ \\
$\mathrm{CP}$ & $0.965 \pm 0.072^{\mathrm{a}}$ & $5.752 \pm 0.081^{\mathrm{a}}$ & $82.16 \pm 1.531^{\mathrm{a}}$ & $8.649 \pm 0.403^{\mathrm{a}}$ \\
AHE lone & $1.711 \pm 0.056^{\mathrm{b}}$ & $2.148 \pm 0.034^{\mathrm{b}}$ & $44.26 \pm 0.385^{\mathrm{b}}$ & $3.599 \pm 0.245^{\mathrm{b}}$ \\
$\mathrm{CP}+$ AHE & $1.237 \pm 0.025^{\mathrm{a}, \mathrm{b}^{*}, \mathrm{~d}^{* *}}$ & $4.498 \pm 0.073^{\mathrm{a}, \mathrm{b}, \mathrm{d}}$ & $68.14 \pm 0.81^{\mathrm{a}, \mathrm{b}, \mathrm{d}}$ & $6.965 \pm 0.214^{\mathrm{a}, \mathrm{b}^{* *}, \mathrm{~d}}$ \\
$\mathrm{AHE}+\mathrm{CP}$ & $1.582 \pm 0.040^{\mathrm{b}, \mathrm{c}^{* *}}$ & $3.049 \pm 0.136^{\mathrm{a}, \mathrm{b}, \mathrm{c}}$ & $50.53 \pm 0.410^{\mathrm{a}^{* *}, \mathrm{~b}, \mathrm{c}}$ & $4.614 \pm 0.184^{\mathrm{b}, \mathrm{c}}$ \\
$\mathrm{CP}+$ Sily & $1.591 \pm 0.075^{\mathrm{b}}$ & $2.99 \pm 0.012^{\mathrm{a}, \mathrm{b}}$ & $50.03 \pm 1.149^{\mathrm{a}^{*}, \mathrm{~b}}$ & $4.396 \pm 0.208^{\mathrm{b}}$ \\
\hline
\end{tabular}

Values expressed as mean \pm SEM. a: Significance at $p<0.0001$ Vs. control group, b: Significance at $p<0.0001$ Vs. Cisplatin (CP) group. C: Significance at $p<0.0001$ of $\mathrm{AHE}+\mathrm{CP}$ pre-treated group Vs. $\mathrm{CP}+\mathrm{AHE}$ post-treated group. d: Significance at $p<0.0001$ of CP + AHE treatment groups Vs CP + Sily group. ${ }^{*}{ }^{* *}:$ Significant difference at $p<0.001$. Non-significant difference $(p>0.05)$ was recorded between control and AHE alone treated group in all parameters (One way ANOVA followed by Tukey's multiple comparison tests)

the level of DNA fragmentation (\%) near to control group.

\section{DNA ladder assay}

DNA was extracted from the pulmonary tissue of the treated rats and different banding configurations were detected in Fig. 1 b. There was found much variation in the genomic DNA banding pattern from the pulmonary tissue of all experimental groups. In case of control group the genomic DNA gave single sharp band without degradation and tail pattern. CP treatment induced DNA damages in pulmonary tissues of rats which showed a peculiar type of continuous pattern of DNA fragmentation of up to $100 \mathrm{bp}$. AHE treatments showed marked repairing of the DNA damage. In the case of $\mathrm{AHE}+\mathrm{CP}$ group there was more significant repairing of DNA damage compared to $\mathrm{CP}+\mathrm{AHE}$ group; which showed partial protective effect (Fig. 1 b).

\section{Histopathology assessment of lungs}

Pulmonary sections of control and AHE alone treated rats revealed the archetypal lung morphology with distinct alveolar septum, alveolar bronchioles, normal pear shape Clara cells, fibroblast, and type I and type II pneumocytes (Fig. 2). CP treatment induced severe degenerations including inflammatory cell infiltrations, alterations in alveolar septum, disruption of connective tissue and elastic fibers, blood vessel congestion, pulmonary edema, disorganized inner epithelium of alveolar bronchioles, fibroblast aggregations and interstitial hemorrhages. AHE $+\mathrm{CP}$ and Sily $+\mathrm{CP}$ treatment groups showed significant protection of pulmonary tissue against the $\mathrm{CP}$ side effects, and preserve morphology toward the control group. Administration of AHE after $\mathrm{CP}$ intoxication showed less protection as compared to its administration before the $\mathrm{CP}$. The histopathological outcomes were in conformity with the results of pulmonary antioxidant enzymes, oxidative stress, lipid peroxidation status and DNA damage analysis.

\section{Discussion}

Numerous drugs and chemotherapies employed in the treatment of various cancers have been associated with pulmonary toxicity [4]. Boosted ROS/RNS assembly persuades frequent DNA damages, impedement of apoptosis and stimulation of proto-oncogenes by prompting various signal transduction pathways that lead to damage of both DNA and protein $[57,58]$. For that reason, it is feasible that enduring inflammation encouraged generation of ROS/RNS in the lung could incline the individuals towards lung cancer. CP administration has been associated with chronic obstructive pulmonary ailment and pulmonary dysfunction in humans, resulting as a consequence of the oxidative stress and deterioration in body's antioxidant status [59]. Therefore, the current investigation aimed at evaluating the protective potential of A. hydaspica AHE (polyphenolic rich fraction) extract against CP induced pulmonary toxicity.

A disproportion between antioxidants and oxidants has been regarded as underlying mechanism in the pathogenesis of lung diseases. The lung has heavy reliance on enzymatic antioxidants i.e., Catalase (CAT), superoxide dismutase (SOD), and glutathione peroxidase (GPx). Our investigation revealed that administration of a single dose of CP induced pulmonary injuriousness in rats through substantial changes in the lung tissue antioxidant status, possibly due to increased lipid peroxidation and ROS generation, which consequently induce oxidative trauma. In the lung tissue of the $\mathrm{CP}$ administered rats, oxidative stress markers (MDA, NO and $\mathrm{H}_{2} \mathrm{O}_{2}$ ) levels were significantly elevated while antioxidant enzymes (SOD, CAT, POD, QR, GPx, $\gamma$ GT GR, GST and GSH) levels were markedly declined. The low GSH-Px activity could be directly explicated by the diminished GSH quantity, for the reason that GSH is a substrate and cofactor of GSH-Px enzyme. As a result, low GSH content implies low GSH-Px activity that may possibly create an amplified oxidative stress tendency. These observations supported the assumption that free radicals play a major role in $\mathrm{CP}$ induced pulmonary 

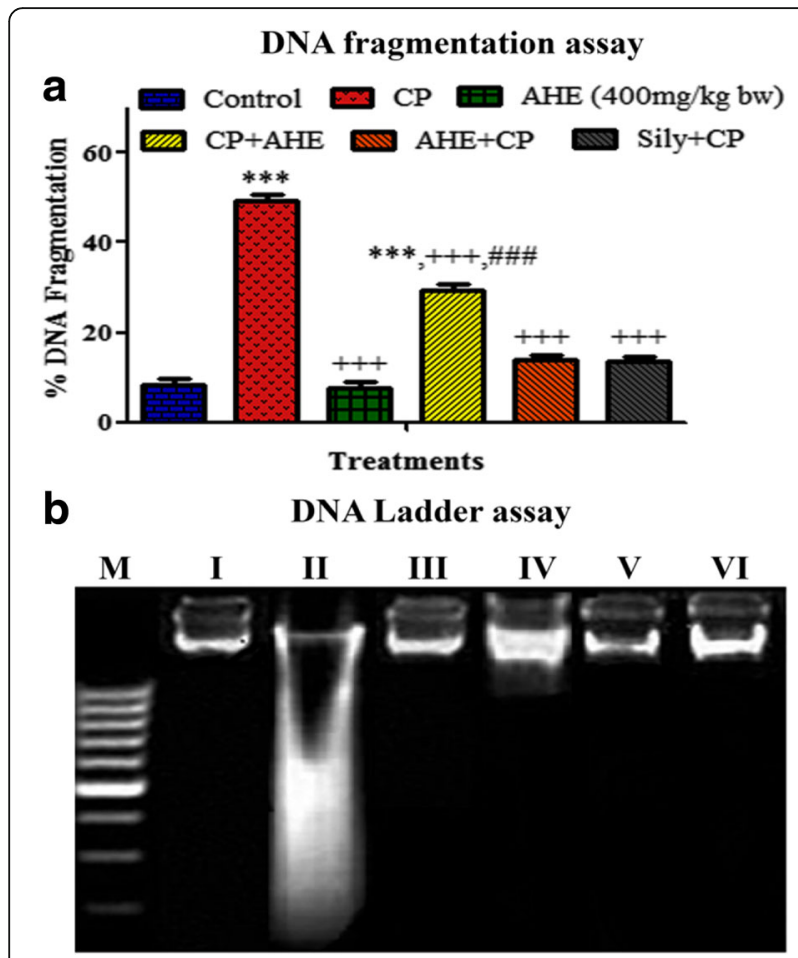

Fig. 1 a DNA fragmentation (\%) in different treatment groups, (b) Agarose gel showing DNA damage by CP and protective effects of Pre and post treatment of AHE and silymarin in pulmonary tissue. Lanes from left (M) low molecular weight marker, (I) control, (II) CP group, (III) AHE (400 mg/kg bw) group, (IV) CP + AHE group, (V) AHE + CP group, (VI) Sily + CP group

toxicity [60]. However, enhanced activity level of SOD, CAT, POD, QR, GPx, GR, $\gamma$ GT, GST and GSH enzyme of lung tissues and significant decrease in lipid peroxidation, $\mathrm{NO}$ and $\mathrm{H}_{2} \mathrm{O}_{2}$ content with AHE treatment may depict shielding ability of AHE to eradicate reactive free radicals generated by $\mathrm{CP}$ induced toxicity. AHE pretreatment seems to be more effective as compared to its administration after injury, and results of pretreatment were comparable to respective silymarin treated groups. Silymarin is a mixture of flavonoid isomers was used as standard extract for comparison. The mechanism action of silymarin is inhibition of lipid peroxidation and enhancement of endogenous antioxidants via its antioxidative and anti-inflammatory potential. Our results were in line with the study of Ayaz and coworkers indicating that pretreatment with methanolic bark extract of Acacia catechu (400 mg/kg body weight) significantly ameliorates benzo(a)pyrene induced increased toxicity markers and activities of detoxifying enzymes along with the levels of glutathione content. The underlying mechanism is the attenuated expression of apoptotic and inflammatory markers in the lungs [33]. Polyphenolic in A. hydaspica AHE fraction might be responsible for the protective effect via diminishing oxidative stress and increasing the antioxidant enzyme status. AHE has been shown to be rich in 7-O-galloyl catechin, catechin and gallic acid; metabolites with well-recognized antioxidant properties [61]. Hassan and colleagues [62] revealed the preventive potential of catechin and apigenin against cisplatin-induced alteration in antioxidant enzymes levels and oxidative stress marker by restoring them to normal. Furthermore, previous studies indicate that Gallic acid significantly deteriorated the inflammatory or fibrotic changes, collagen content, levels of MDA, and pro-inflammatory cytokines such as TNF- $\alpha$ and IL1 $\beta$ in pulmonary tissue of bleomycin treated rats. Gallic acid attenuates oxidative damage and reversed histopathological alterations induced by bleomycin by its antioxidant properties [35]. Similarly catechin a major component in AHE has shown protective potential against various toxicants i.e. catechin ameliorates chlorpyrifos-induced lung toxicity by restoring the activity of mitochondrial complex I and ATP biosynthesis [63]. Catechin compound was also able to restore the imbalance in superoxide dismutase and catalase activities as well as the decrease in NO levels induced by amiodarone. Protein and lipid oxidative damage and cell death were reduced by catechin and epicatechin in amiodarone -treated lung cells [64]. Various other studies involving catechin-rich fractions from other plants have demonstrated antineoplastic, antioxidant and antiinflammatory properties [65]. As a consequence, it is not surprising that AHE extract of A. hydaspica exhibit protective potential because of the presence of catechins and flavonoids.

In the lung tissues, genotoxicity is of two types; direct genotoxic effects like DNA damage and induction of mutation or indirect effect caused by enzymes like cytochrome P-450 oxidase, flavin monooxidases etc., that generates ROS in the cells which leads to damage of both DNA and protein [57]. Oxidative stress causes intensification in oxidative DNA damage underlying various degenerative diseases [39]. In current finding, elevated levels of DNA fragmentation in CP administered group indicated the DNA damage through generation of free radicals. Previous finding have also been described that $\mathrm{CP}$ induce oxidative stress and genotoxicity with creation of DNA adducts and genetic alterations in various organs for instance brain [66], testis [67], stomach and lungs [68] etc. Relatively lesser amount of DNA fragmentation in AHE pretreated group point toward the protective role of AHE for lung tissues that was further confirmed by DNA ladder assay.

Histopathological examination revealed disruption in the alveolar septa, overcrowding of the blood capillaries, and thickening of alveolar walls, increase in fibroblast number, dilation of clara cells toward the lumen of the bronchiole, narrow lumen and necrosis of the alveolar epithelium in $\mathrm{CP}$ treated group. The disturbed 


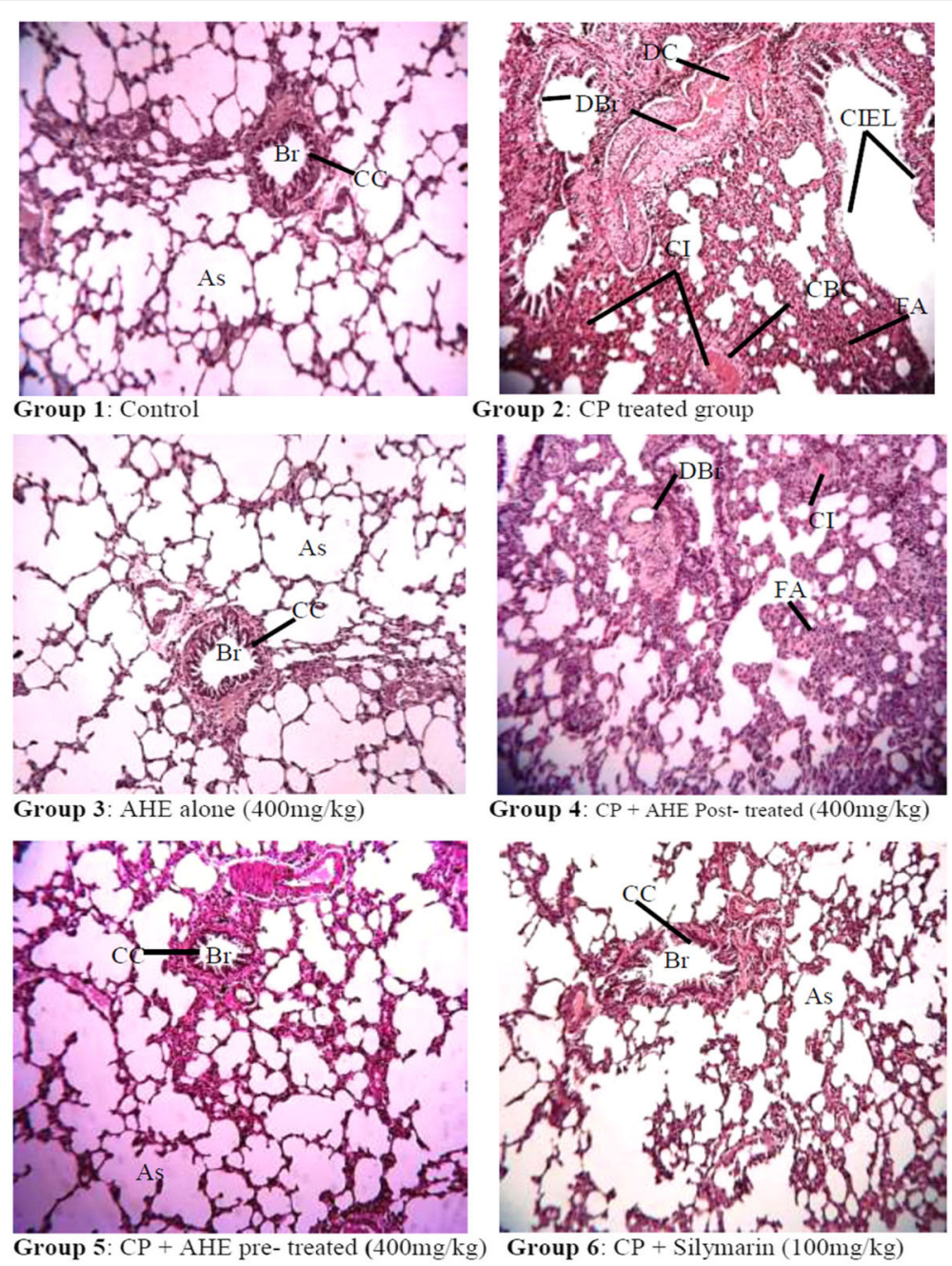

Fig. 2 Histopathological effect of cisplatin and protective effect of AHE in rat Lungs. (H\&E staining; magnification 40X). Group 1: Lung tissue section from control rats showing normal morphology. Group 2: tissue sections from CP-treated rats show degenerative changes, atrophy and cellular infiltrations. Group 3: Represents lung section from AHE alone treated rats. Group 4: AHE Post-treatment showed mild disorganizations, cellular infiltrations and fibroblast aggregations. Group 5: AHE Pre-treatment showed significant protection against CP-induced lung injury. Group 6: Showed protective effect of Silymarin treatment. AHE- A. hydaspica ethyl acetate fraction, CP-Cisplatin, Br-Bronchioles, As-Alveolar septum, CC-Clara cells, T- Tubules, Cl- Cellular infiltrations, DBr-Disorganized bronchioles, FA- fibroblast aggregations, CIEL-collapsed inner epithelial cells

histological structure of pulmonary tissues may be liable to make clear the potential of oxidative stress induced by $\mathrm{CP}$ to intoxicate the pulmonary tissues. Oxidative trauma induced by CP might link with morphological deteriorations; as free radicals have the aptitude to harm nucleic acids, proteins, and lipids. Resultantly they outcome in deterioration of enzymatic activity, initiate DNA strand breaks, lipid peroxidation, initiate cellular damage and structural disruption [69]. Effects of CP might be analogous to that of bleomycin intoxication indicating serious collapsed alveoli, epithelial damage, considerably thick inter alveolar septa with those of fibroblasts, and inflammatory cells infiltration [70]. Ethyl acetate fraction (AHE) of A. hydaspica suppressed CP intoxication in pulmonary tissues as displayed by a clear decrease in interstitial infiltration and collagen content. Histopathological examination supports the biochemical findings as illustrated by noteworthy lessening in pulmonary damage when AHE was used as a pre-treatment agent before $\mathrm{CP}$ administration. Pretreatment maintained the normal histological characteristics of the pulmonary cells. This indicates that administration of AHE prior to CP impede the free radicals generation and prevent cellular damages. In $\mathrm{CP}$ treated rats lung tissues are more prone to in vivo infection and inflammation. Therefore, suppression of lung inflammations may be significant for protection against $\mathrm{CP}$ induced toxicity to lung tissues. Pulmonary inflammatory reactions and edema are definitely associated with working of lung, includes pulmonary tract stress and oxygenation index [71]. Suppression 
of reactive species generation inhibited inflammation of lungs and damage in different models. Groups administered with AHE demonstrated considerable reduction in number of alveolar macrophages to decrease of epithelial damage and inflammatory cellular infiltration induced by $\mathrm{CP}$. Previous reports have also confirmed the beneficial effects of antioxidants in pulmonary fibrosis. Phytochemicals in AHE comprising of flavan-3-ols (7-Ogalloyl catechin, catechin) and methyl gallate were potentially responsible for observed protection against oxidative damage. Bors et al. also revealed that flavan-3-ols and flavonols are predominant antioxidants due to the existence of a 3-OH connected with the catechol $\left(3^{\prime}, 4^{\prime}\right.$ dihydroxyl) unit [72]. Furthermore a study by Uzun and coworkers [63] revealed that catechin compound has ability prevents lung fibrosis and lessens histopathological changes in chlorpyrifos-induced lung toxicity. Recently, Lim and his colleagues evaluated the pharmacological impact of a Morus alba total extract (flavonoid rich) on inflammation of airways and observed a noteworthy decline in the overall amount of inflammatory cells and production of inflammatory mediators viz. TNF- $\alpha$, IL- 6 and NO by lung macrophages [73].

\section{Limitations of the study}

Before making a definite statement about the possible suitability of AHE as an assistant to $\mathrm{CP}$ medications; additional studies are prerequisite to be undertaken in order to explicate the mechanism at the molecular level. For this western blot analysis and immunohistochemistry would provide information regarding signaling pathway in the pathogenesis of lung damage and protection afforded by Plant extract. Moreover the effect of plant extract at different dose levels and cancer models will provide knowledge on whether the extract interferes with anticancer ability of $\mathrm{CP}$ or not. Further studies using isolated compounds also help to determine the exact mechanism of action and to better ascertain the active compounds, and to find out if the pretreatment mitigates/abrogates the anti-cancer efficacy of CP.

\section{Conclusion}

The results here suggest that deleterious side effects of $\mathrm{CP}$ may be restricted by the administration of AHE as a pretreatment agent. The underlying mechanism of protection is augmentation of endogenous antioxidant defense, diminished oxidative stress and inhibition of DNA damage.

\section{Abbreviations}

AHE: Acacia hydaspica ethyl-acetate extract; ARDS: Acute respiratory distress syndrome; CAT: Catalase; COPD: Chronic Obstructive Pulmonary Disease; CP: Cisplatin; EGCG: Epigallocatechin gallate; GPX: Glutathione peroxidase; $\mathrm{H}_{2} \mathrm{O}_{2}$ : Hydrogen peroxide; IL: Interleukins; MDA: Malonyldialdehyde;
NADPH: Nicotinamide adenine dinucleotide phosphate; NO: Nitric oxide; SOD: superoxide dismutase; TBARS: Thiobarbituric acid reactive substances; TNF: Tumor necrosis factor

\section{Acknowledgements}

We acknowledge Higher Education Commission (HEC) of Pakistan for awarding indigenous scholarship for $\mathrm{PhD}$ research to the first author. The authors would like to extend their sincere appreciation to the Deanship of Scientific Research College of Applied Medical Sciences, Research Center at King Saud University.

\section{Funding}

The project was partially funded by the Higher Education Commission (HEC) of Pakistan by awarding indigenous scholarship to the first author. We are grateful to the Deanship of the Scientific Research, College of Applied Medical Sciences, Research Center at King Saud University.

\section{Availability of data and materials}

All data generated or analyzed during this study are included in this published article. The raw used and/or analyzed during the current study can be available from the corresponding author on reasonable request.

\section{Authors' contributions}

TA made significant contributions to conception, design, experimentation, acquisition and interpretation of data and writing of manuscript. SR made substantial contribution in experimentation, writing and revising the manuscript for important intellectual content. AA and MRK made substantial contribution in interpretation of data and revising the manuscript for important intellectual content. All authors have read and approved the final manuscript.

\section{Ethics approval and consent to participate}

This investigation involved testing on rats, and the experimental protocol for the testing on animal was approved (Bch\#0256) by the ethical board of

Quaid-i-Azam University, Islamabad, Pakistan.

\section{Consent to publication}

Not applicable

\section{Competing interests}

The authors declare that they have no competing interest.

\section{Publisher's Note}

Springer Nature remains neutral with regard to jurisdictional claims in published maps and institutional affiliations.

\section{Author details}

${ }^{1}$ Department of Biochemistry, Faculty of Biological Sciences, Quaid-i-Azam University, Islamabad, Pakistan. ${ }^{2}$ Department of Animal Sciences, Faculty of Biological Sciences, Quaid-i-Azam University, Islamabad, Pakistan.

${ }^{3}$ Department of Community Health Sciences, College of Applied Medical Sciences, King Saud University, Riyadh, Saudi Arabia.

Received: 13 June 2017 Accepted: 25 January 2018

Published online: 02 February 2018

\section{References}

1. Zielinski NA, Roychoudhury S, Chakrabarty AM. Regulation of alginate gene expression in Pseudomonas Aeruginosa. Methods Enzymol. 1994; 235:493-502.

2. Mimoto J, Kiura K, Matsuo K, Yoshino T, Takata I, Ueoka H, Kataoka M, Harada M. (-)-Epigallocatechin gallate can prevent cisplatin-induced lung tumorigenesis in a/J mice. Carcinogenesis. 2000;21(5):915-9.

3. Batist $G$, Andrews JL. Pulmonary toxicity of antineoplastic drugs. JAMA. 1981;246(13):1449-53.

4. Cooper J Jr, White DA, Matthay RA. Drug-induced pulmonary disease. Part 1: Cytotoxic drugs. Am Rev Respir Dis. 1986;133(2):321-40.

5. Chen $Y$, Jungsuwadee $P$, Vore $M$, Butterfield DA, St Clair DK. Collateral damage in cancer chemotherapy: oxidative stress in nontargeted tissues. Mol Interv. 2007;7(3):147.

6. Dasari S, Tchounwou PB. Cisplatin in cancer therapy: molecular mechanisms of action. Eur J Pharmacol. 2014;740:364-78. 
7. Leo F, Pelosi G, Sonzogni A, Chilosi M, Bonomo G, Spaggiari L. Structural lung damage after chemotherapy: fact or fiction? Lung Cancer. 2010;67(3):306-10.

8. Pratibha R, Sameer R, Rataboli PV, Bhiwgade DA, Dhume CY. Enzymatic studies of cisplatin induced oxidative stress in hepatic tissue of rats. Eur J Pharmacol. 2006;532(3):290-3.

9. Nel AE, Diaz-Sanchez D, Li N. The role of particulate pollutants in pulmonary inflammation and asthma: evidence for the involvement of organic chemicals and oxidative stress. Curr Opin Pulm Med. 2001;7(1):20-6.

10. Ali BH, Al Moundhri MS. Agents ameliorating or augmenting the nephrotoxicity of cisplatin and other platinum compounds: a review of some recent research. Food Chem Toxicol. 2006;44(8):1173-83.

11. Yagmurca M, Bas O, Mollaoglu H, Sahin O, Nacar A, Karaman O, Songur A Protective effects of erdosteine on doxorubicin-induced hepatotoxicity in rats. Arch Med Res. 2007;38(4):380-5.

12. Yousef M, Saad A, El-Shennawy L. Protective effect of grape seed proanthocyanidin extract against oxidative stress induced by cisplatin in rats. Food Chem Toxicol. 2009;47(6):1176-83.

13. Sahreen S, Khan MR, Khan RA. Evaluation of antioxidant activities of various solvent extracts of Carissa Opaca fruits. Food Chem. 2010;122(4):1205-11.

14. Khan RA, Khan MR, Sahreen S, Ahmed M. Evaluation of phenolic contents and antioxidant activity of various solvent extracts of Sonchus Asper (L.) hill. Chem Cent J. 2012;6(1):12.

15. Dai J, Mumper RJ. Plant phenolics: extraction, analysis and their antioxidant and anticancer properties. Molecules. 2010;15(10):7313-52.

16. Sak K. Chemotherapy and dietary phytochemical agents. Chemother Res Pract. 2012;2012:1-11.

17. Mukherjee PK, Wahile A. Integrated approaches towards drug development from Ayurveda and other Indian system of medicines. J Ethnopharmacol. 2006;103(1):25-35.

18. Bursal E, Gülçin I. Polyphenol contents and in vitro antioxidant activities of lyophilised aqueous extract of kiwifruit (Actinidia Deliciosa). Food Res Int. 2011:44(5):1482-9.

19. Sahreen S, Khan MR, Khan RA. Phenolic compounds and antioxidant activities of Rumex Hastatus D. Don. Leaves. J Med Plants Res. 2011; 5(13):2755-65

20. Sakthivel K, Kannan N, Angeline A, Guruvayoorappan C. Anticancer activity of Acacia Nilotica (L.) wild. Ex. Delile Subsp. Indica against Dalton's ascitic lymphoma induced solid and ascitic tumor model. Asian Pac J Cancer Prev. 2012;13(8):3989-95.

21. Singh R, Singh B, Singh S, Kumar N, Kumar S, Arora S. Umbelliferone-an antioxidant isolated from Acacia Nilotica (L.) Willd. Ex. del. Food Chem. 2010; 120(3):825-30

22. Tung Y-T, Wu J-H, Huang C-C, Peng H-C, Chen Y-L, Yang S-C, Chang S-T. Protective effect of Acacia Confusa bark extract and its active compound gallic acid against carbon tetrachloride-induced chronic liver injury in rats. Food Chem Toxicol. 2009;47(6):1385-92.

23. Meena PD, Kaushik P, Shukla S, Soni AK, Kumar M, Kumar A. Anticancer and antimutagenic properties of Acacia Nilotica (Linn.) on 7, 12-dimethylbenz (a) anthracene-induced skin papillomagenesis in Swiss albino mice. Asian Pac J Cancer Prev. 2006:7(4):627-32.

24. Malviya S, Rawat S, Kharia A, Verma M. International journal of pharmacy \& life sciences. Int J Pharm Life Sci(IJPLS). 2011;2(6):830-7.

25. Chakrabarty T, Gangopadhyay M. The genus acacia P. Miller (Leguminosae: Mimosoideae) in India. J Econ Taxon Bot. 1996:20(3):599-633.

26. Jabeen A, Khan MA, Ahmad M, Zafar M, Ahmad F. Indigenous uses of economically important flora of Margallah hills national park, Islamabad, Pakistan. Afr J Biotechnol. 2009;8(5):763-84.

27. Afsar T, Khan MR, Razak S, Ullah S, Mirza B. Antipyretic, anti-inflammatory and analgesic activity of Acacia Hydaspica R. Parker and its phytochemical analysis. BMC Complement Altern Med. 2015;15(1):136.

28. Afsar T, Razak S, Khan MR, Mawash S, Almajwal A, Shabir M, Haq IU. Evaluation of antioxidant, anti-hemolytic and anticancer activity of various solvent extracts of Acacia Hydaspica R. Parker aerial parts. BMC Complement Altern Med. 2016;16:258-74.

29. Afsar T, Trembley JH, Salomon CE, Razak S, Khan MR, Ahmed K. Growth inhibition and apoptosis in cancer cells induced by polyphenolic compounds of Acacia Hydaspica: involvement of multiple signal transduction pathways. Sci Rep. 2016;6:23077.

30. Afsar T, Razak S, Khan MR, Almajwal A. Anti-depressant and anxiolytic potential of Acacia Hydaspica R. Parker aerial parts extract: modulation of brain antioxidant enzyme status. BMC Complement Altern Med. 2017;17(1):228.

31. Puga CD, Hilario MC, Mendoza JGE, Campos OM, Jijón EM, Martínez MD, Izazaga MAÁ, Solano JÁL, Chaverri JP. Antioxidant activity and protection against oxidative-induced damage of Acacia Shaffneri and Acacia Farnesiana pods extracts: in vitro and in vivo assays. BMC Complement Altern Med. 2015;15(1):435

32. Afsar T, Razak S. Modulatory influence of Acacia Hydaspica R. Parker ethyl acetate extract against cisplatin inveigled hepatic injury and dyslipidemia in rats. BMC Complement Altern Med. 2017;17(1):307.

33. Shahid A, Ali R, Ali N, Kazim Hasan S, Barnwal P, Mohammad Afzal S, Vafa A, Sultana S. Methanolic bark extract of Acacia Catechu ameliorates benzo (a) pyrene induced lung toxicity by abrogation of oxidative stress, inflammation, and apoptosis in mice. Environ Toxicol. 2017;32(5):1566-77.

34. Aliyu M, Ibrahim S, Inuwa HM, Sallau AB, Abbas O, Aimola IA, Habila N, Uche NS. Ameliorative effects of acacia honey against sodium arsenite-induced oxidative stress in some viscera of male Wistar albino rats. Biochem Res Int. 2013;2013:622-8.

35. Nikbakht J, Hemmati AA, Arzi A, Mansouri MT, Rezaie A, Ghafourian M. Protective effect of gallic acid against bleomycin-induced pulmonary fibrosis in rats. Pharmacol Rep. 2015;67(6):1061-7.

36. Ferk F, Chakraborty A, Jäger W, Kundi M, Bichler J, Mišík M, Wagner K-H, Grasl-Kraupp B, Sagmeister S, Haidinger G. Potent protection of gallic acid against DNA oxidation: results of human and animal experiments. Mutat Res. 2011;715(1):61-71.

37. Sato K, Kiura K, Tabata M, Kishino D, Okada T, Hosokawa S, Kozuki T, Ueoka $H$, Hara Y, Masferrer J. Effect of cyclooxygenase-2 inhibitor in combination with (-)-epigallocatechin gallate or polyphenon $E$ on cisplatin-induced lung tumorigenesis in a/J mice. Cancer Res. 2005;65(9 Supplement):1427-8.

38. Azu OO, Francis I, Abraham A, Crescie C, Stephen O, Abayomi O. Protective agent, Kigelia Africana fruit extract, against Cisplatin-induced kidney oxidant injury in Sprague-Dawley rats. Asian J Pharma Clin Res. 2010;3:84-8.

39. Guideline OO. 425: acute oral toxicity-up-and-down procedure. OECD Guidel Test Chem. 2001:2:12-6.

40. Irwin S. Comprehensive observational assessment: la. A systematic, quantitative procedure for assessing the behavioral and physiologic state of the mouse. Psychopharmacology. 1968;13(3):222-57.

41. Mensah A, Mireku E, Mensah M, Amponsah I. Some neurological effects of the ethanolic stem bark extract of Cussonia bancoensis Aubrev and Pellgr (Araliaceae). J Pharmacogn Phytochem. 2014;2(6):101-6.

42. Nasr AY, Saleh HA. Aged garlic extract protects against oxidative stress and renal changes in cisplatin-treated adult male rats. Cancer Cell Int. 2014;14(1):92.

43. El-Halim SSA, Mohamed MM. Garlic powder attenuates Acrylamide-induced oxidative damage in multiple organs in rat. J Appl Sci Res. 2012:8(1):168-73.

44. Yadav YC, Srivastava D. Nephroprotective and curative effects of Ficus Religiosa latex extract against cisplatin-induced acute renal failure. Pharm Biol. 2013:51(11):1480-5.

45. Lowry OH, Rosebrough NJ, Farr AL, Randall RJ. Protein measurement with the Folin phenol reagent. J Biol Chem. 1951;193(1):265-75.

46. Chance B, Maehly A: [136] assay of catalases and peroxidases. 1955.

47. Kakkar P, Das B, Viswanathan P. A modified spectrophotometric assay of superoxide dismutase. Indian J Biochem Biophys. 1984;21(2):130-2.

48. Benson AM, Hunkeler MJ, Talalay P. Increase of NAD (P) H: quinone reductase by dietary antioxidants: possible role in protection against carcinogenesis and toxicity. Proc Natl Acad Sci. 1980;77(9):5216-20.

49. Jollow D, Mitchell J, Zampaglione NA, Gillette J. Bromobenzene-induced liver necrosis. Protective role of glutathione and evidence for 3, 4bromobenzene oxide as the hepatotoxic metabolite. Pharmacology. 1974; 11(3):151-69.

50. Habig WH, Pabst MJ, Jakoby WB. Glutathione S-transferases the first enzymatic step in mercapturic acid formation. J Biol Chem. 1974; 249(22):7130-9.

51. Carlberg I, Mannervik B. Purification and characterization of the flavoenzyme glutathione reductase from rat liver. J Biol Chem. 1975;250(14):5475-80.

52. Mohandas J, Marshall JJ, Duggin GG, Horvath JS, Tiller DJ. Differential distribution of glutathione and glutathione-related enzymes in rabbit kidney: possible implications in analgesic nephropathy. Biochem Pharmacol. 1984;33(11):1801-7.

53. Orlowski M, Sessa G, Green JP. Y-Glutamyl transpeptidase in brain capillaries: possible site of a blood-brain barrier for amino acids. Science. 1974; 184(4132):66-8 
54. lqbal S, Bhanger M, Anwar F. Antioxidant properties and components of some commercially available varieties of rice bran in Pakistan. Food Chem. 2005;93(2):265-72.

55. Pick E, Mizel D. Rapid microassays for the measurement of superoxide and hydrogen peroxide production by macrophages in culture using an automatic enzyme immunoassay reader. J Immunol Methods. 1981; 46(2):211-26.

56. Green LC, Wagner DA, Glogowski J, Skipper PL, Wishnok JS, Tannenbaum SR. Analysis of nitrate, nitrite, and [15 N] nitrate in biological fluids. Anal Biochem. 1982;126(1):131-8.

57. Petruska JM, Mosebrook DR, Jakab GJ, Trush MA. Myeloperoxidaseenhanced formation of ( \pm )-trans-7, 8-dihydroxy-7, 8-dihydrobenzo [a] pyrene adducts in lung tissue in vitro: a role of pulmonary inflammation in the bioactivation of a procarcinogen. Carcinogenesis. 1992;13(7):1075-81.

58. Belinsky SA, Nikula KJ, Palmisano WA, Michels R, Saccomanno G, Gabrielson E, Baylin SB, Herman JG. Aberrant methylation of p16INK4a is an early event in lung cancer and a potential biomarker for early diagnosis. Proc Natl Acad Sci. 1998;95(20):11891-6.

59. Ismail M, Hossain MF, Tanu AR, Shekhar HU. Effect of Spirulina intervention on oxidative stress, antioxidant status, and lipid profile in chronic obstructive pulmonary disease patients. Biomed Res Int. 2015;2015:710-17.

60. Injac R, Radic N, Govedarica B, Perse M, Cerar A, Djordjevic A, Strukelj B. Acute doxorubicin pulmotoxicity in rats with malignant neoplasm is effectively treated with fullerenol C $60(\mathrm{OH}) 24$ through inhibition of oxidative stress. Pharmacol Rep. 2009;61(2):335-42.

61. Zhao C, Li C, Liu S, Yang L. The galloyl catechins contributing to main antioxidant capacity of tea made from Camellia Sinensis in China. Sci World J. $2014 ; 2014$.

62. Hassan SM, Khalaf MM, Sadek SA, Abo-Youssef AM. Protective effects of apigenin and myricetin against cisplatin-induced nephrotoxicity in mice. Pharm Biol. 2017;55(1):766-74.

63. Uzun FG, Demir F, Kalender S, Bas H, Kalender Y. Protective effect of catechin and quercetin on chlorpyrifos-induced lung toxicity in male rats. Food Chem Toxicol. 2010;48(6):1714-20.

64. Santos LFS, Stolfo A, Calloni C, Salvador M. Catechin and epicatechin reduce mitochondrial dysfunction and oxidative stress induced by amiodarone in human lung fibroblasts. J Arrhythmia. 2016;2016:220-5.

65. Stohs SJ, Bagchi D. Antioxidant, anti-inflammatory, and chemoprotective properties of Acacia Catechu heartwood extracts. Phytother Res. 2015; 29(6):818-24.

66. Gulec M, Oral E, Dursun OB, Yucel A, Hacimuftuoglu A, Akcay F, Suleyman $H$. Mirtazapine protects against cisplatin-induced oxidative stress and DNA damage in the rat brain. Psychiatry Clin Neurosci. 2013;67(1):50-8.

67. Köberle B, Masters JR, Hartley JA, Wood RD. Defective repair of cisplatininduced DNA damage caused by reduced XPA protein in testicular germ cell tumours. Curr Biol. 1999;9(5):273-8.

68. Geyikoglu F, Isikgoz H, Onalan H, Colak S, Cerig S, Bakir M, Hosseinigouzdagani M, Koc K, Erol HS, Saglam YS. Impact of high-dose oleuropein on cisplatininduced oxidative stress, genotoxicity and pathological changes in rat stomach and lung. J Asian Nat Prod Res. 2017;(12):1-18.

69. Venkatesan N, Punithavathi D, Arumugam V. Curcumin prevents adriamycin nephrotoxicity in rats. Br J Pharmacol. 2000;129(2):231-4.

70. Mall G, Zimmermann P, Siemens I, Burkhardt A, Otto HF. Prevention of bleomycin-induced fibrosing alveolitis with indomethacin: stereological studies on rat lungs. Virchows Archiv A. 1991;419(4):339-47.

71. Chu P-Y, Chien S-P, Hsu D-Z, Liu M-Y. Protective effect of sesamol on the pulmonary inflammatory response and lung injury in endotoxemic rats. Food Chem Toxicol. 2010;48(7):1821-6.

72. Bors W, Heller W, Michel C, Stettmaier K. Flavonoids and polyphenols: chemistry and biology. Antioxidants in Health and Disease Series. 1996;(1):40968 .

73. Lim HJ, Jin H-G, Woo E-R, Lee SK, Kim HP. The root barks of Morus Alba and the flavonoid constituents inhibit airway inflammation. J Ethnopharmacol. 2013;149(1):169-75.

\section{Submit your next manuscript to BioMed Central and we will help you at every step:}

- We accept pre-submission inquiries

- Our selector tool helps you to find the most relevant journal

- We provide round the clock customer support

- Convenient online submission

- Thorough peer review

- Inclusion in PubMed and all major indexing services

- Maximum visibility for your research

Submit your manuscript at www.biomedcentral.com/submit
Biomed Central 